Int.J. Hum. Soc. Dev. Res.

ISSN (P):2521-1439; ISSN (E):2523-4331

Volume 3, № 1, 2019. 32-44

DOI: $10.30546 / 2523-4331.2019 .3 .1 .32$

\title{
THE INTERFERENCE OF TURKISH LANGUAGE SYNTAX IN THE LEARNING PROCESS OF FRENCH-LANGUAGE LEARNERS
}

\section{Behrooz RAHNAMAYEKOOYAN}

University of Tarbiat Modares, Iran

\section{Shiva HEMMATI}

Daneshvaran University, Tabriz, Iran

(C) The Author(s) 2019

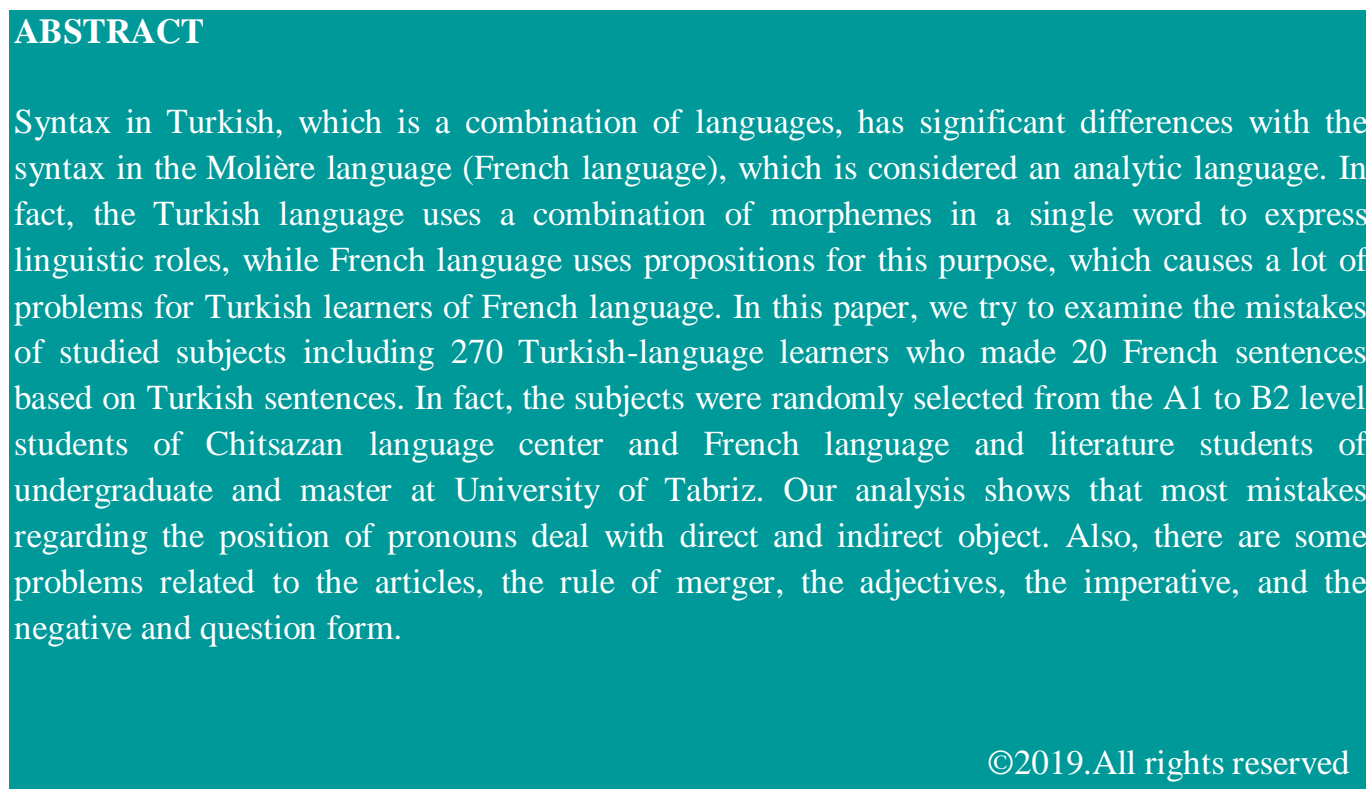

ARTICLE HISTORY

Received: 29/12/2018

Accepted: 19/03/2019

Published online: 01/04/2019

\section{KEYWORDS}

Turkish language Syntax; learning Process of Frenchlanguage; the position of pronouns, articles, the adjectives, the imperative, the negative and question form.

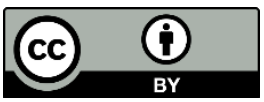

www.ijhsdr.com 


\section{Introduction}

When learning a foreign language, the contact of the native language learner with this foreign language sometimes leads to the transfer of language habits of the source language in the teaching/ learning process, including syntactic interactions. In fact, syntax plays a significant role in the process by monitoring the arrangement and position of the vocabularies in the sentence. Fries and Lado believe that the similarities between mother tongue and foreign language reduce the mistakes of learners, while the differences between these two increase the learning mistakes greatly. However, it should also be noted that this does not include all cases. Therefore, it seems that a French-language learner has difficulty dealing with a lot of syntactic problems, since Turkish and French languages have significant differences in terms of word order. In other words, the Turkish language is one of the combined languages, in which takes several morphemes in a single word to provide linguistic roles, but French is an analytical language using independent words (propositions) to express these roles, and vocabularies in the sentences of this language are relatively independent of each other. Thus, the importance of assessing the influence of the Turkish language syntax is highlighted among Turkish learners of French. To this end, we attempt to determine the extent of its impact within the framework of this research based on our analytical study. It should be noted that while studying and analysing the errors and mistakes in the text body, our efforts is based more on the diagnostic or descriptive view of contrastive analysis.

Texture body of this research consists of 20 sentences made by French language learners. These subjects are from Tabriz city located in the East Azerbaijan province. Although Persian is considered as the official language of the country, the Turkish language is still considered the main language of people in Tabriz. In fact, the language of Tabriz is Azeri Turkish, a main subdivision of Turkish language. In this study, the studied subjects were asked to translate 20 Turkish sentences in French. These 20 sentences are presented in writing form in both the Latin and Arabic alphabets, and the translation of these sentences are in Persian, and also the Turkish phonetic writing (IPA) has been added to it, since most Turkish speakers of Iran do not have the ability to write and read their mother language as they should. But few of the Turkish speakers in the city who are fluent in their language are those who have learned this language by selfstudying Arabic or Latin writing. In other words, the Azeri Turkish is limited to verbal speech, which causes the effect of other language factors and even the interference of other dominant languages in the process of learning French language. It should also be noted that in the analysis of this research, the International Phonetic Writing (IPA) of

Int.J. Hum. Soc. Dev. Res.

Volume 3, № 1, 2019. 32-44 
the Standard Azeri Turkish Language has also been included. In particular, it should be noted that the studied subjects were randomly selected from the bachelor and master students of French language and literature at the University of Tabriz and among the students of Chitsazan language center from A1 to B2 levels. The total number of subjects is 270 , which includes both genders. They perform this assignment within an hour, and at the same time, a lecturer helps the learners to pronounce and provide equivalent French vocabulary to focus only on the word order and making sentence.

\section{Analysis}

In this research, the criteria for the correction and review of translations is made on the basis of their correspondence with the standard French language. Therefore, this test is not based on communicating and transmitting a language message that ignores structural and grammatical errors.

1. O kitabdan istifadə edir. (written)

0 kItab dan Istıfadæ edir (Standard Azeri Turkish)

il livre de usage fait

[0 kıtabdan Istıfadæ elır] (Turkish accent)

$=$ Il se sert du livre. (He uses the book.)

Or

= Il fait usage du livre. (He uses the book.)

What is said in the first sentence should be acknowledged that the studied subjects have a particular tendency to use the verb "utiliser" in comparison to other alternative expressions and verbs. It should be noted that the standard French written language recommends that the verb "se servir" be used more in the case of first sentence. Other surveys lead us to several other important points, the first one relates to the wrong use of the proposition "de". In fact, when using the verb "utiliser", learners have also added the proposition "de" to it, which has been influenced by their mother tongue, because the verb "use" in Turkish is supplemented with a proposition while this is not acceptable in French.

Another issue that attracts our attention is that $85.71 \%$ of A1 language learners, while using the verb "se servir" in their sentence structure, have neglected the article of "livre" as well as the rule of merger. In fact, the Turkish language lacks the article and the rule of merger. 
2. O İranlı q1zın qalada olduğunu bilirdi.

$\varnothing$

○ Iranlu guz un galad a olduyunu bil

il iranien fille aff. génit. château à présence savoir (rad.) aff. imp. $3^{\mathrm{e}}$ pers. sing.

[o Iranne guzun gælædæ olduyune bylyrde]

= Il savait que la fille iranienne était dans le château. (He knows that the Iranian girl is inside the castle.)

In the second sentence, the adjective of nationality is mistakenly preceded the noun by the learners, which it results from the order of words in the Turkish language (A1A2: $57 / 14 \%$, B1-B2: $12 / 5 \%$, Bachelor \& Master: 0\%). But the other problem encountered by Turkish students is the clear effect of Persian language. In fact, learners of the elementary levels have added the proposition "de" between the word "fille" and the "Iranienne", which is directly related to the Persian language. It should also be noted that Persian as the official language of the country not only affected the vocabularies of Turkish language, but also changed the language to a certain extent in the structure and arrangement of words.

3. Ona baxma!

$\begin{array}{ccccc}\text { on } & \text { a } & \text { bax } & \text { ma } & \varnothing \\ \text { le } & \text { à } & \text { regarder (rad.) } & \text { nég. } & 2^{\mathrm{e}} \text { pers. sing. (impér.) }\end{array}$

[ona baxma] (pas de différence)

$=$ Ne le regarde pas ! (Do not look at that!)

Since the verb "look at" is used with a proposition in Turkish language, $71.42 \%$ of A1-B2 students mistakenly used indirect object pronoun instead of direct one, as a result, they also used its order wrongly. On the other hand, the Turkish grammar uses the same pronoun for reflective, direct or indirect object pronouns that are distinguished only by specific prefixes. Therefore, this has caused $57.28 \%$ of the A1 levels to encounter problems in making their sentences. Even if we assume that the verb "regarder" is used with the proposition "à", a number of learners also put the pronoun "il" after "à"!

4. Onu ona ver!

$\begin{array}{lllll}\text { on } & \mathrm{u} & \text { on } & \mathrm{a} & \text { ver }\end{array}$

Int.J. Hum. Soc. Dev. Res.

Volume 3, № 1, 2019. 32-44 
le aff. accus. le à donner (rad.) $\quad 2^{\mathrm{e}}$ pers. sing. (impér.)

[one ona ver]

$=$ Donne-le-lui ! (Give that to him!)

In this part, the significant problem that can be seen is the lack of attention of learners toward the elimination of "s" from the end of the second person singular verb in French sentences, and $12.5 \%$ of the A1-A2 levels have forgotten to change the place of pronouns in sentences, and they have brought them before verb, which is strange in the French language, and it probably results from the effect of learners' native language.

5. Öz kitabınızı mənə verin !

œz kitab unuz mæn $æ$

verin

morph. emph. (poss.) livre votre aff. accus. je à donnez

[œz kitabuze mænæ verın]

= Donnez-moi votre propre livre ! (Give me your own book.)

In this sentence, the only thing that has attracted our attention is again the place of pronouns. Indeed, in Turkish-language sentences, the indirect object pronouns preceded direct object pronouns, and this has led $7 \%$ of the beginners to use the pronoun 'me' before the verb "donner ", and such order of words is not acceptable in French.

6. Sonra o ağlamağa başladı.

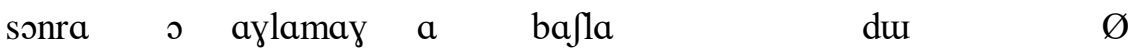

ensuite il pleurer à commencer (rad.) aff. passé $\quad 3^{\mathrm{e}}$ pers. sing.

[sora s aylamaya baflade]

= Ensuite, il s'est mis à pleurer. (Then he started to cry.)

The first mistake in making this sentence is ignoring the use of pronoun "à" after "se mettre" or "commencer", but the second error is associated with the lack of use of gerund after the pronoun (37/03\%). Also, a small number of studied students used the pronoun "de" instead of pronoun "à" after gerund.

7. Kim gəldi?

kım Jæl di $\quad \varnothing$ 
qui venir (rad.) aff. passé $\quad 3^{\mathrm{e}}$ pers. sing.

[kim Jælde]

= Qui est-ce qui est venu ? (Who came?)

Turkish language has "kim" for two identical phrases of "que est-ce qui" and "qui est-ce que" in its system, so most elementary-level learners have encountered a problem and mistakenly used the term "qui est-ce que" in their sentences. In addition, a limited number has used auxiliary verb "avoir" instead of "être", which is considered wrong in French. This mistake can be derived from the lack of auxiliary verbs in Turkish language, while The French language uses auxiliary verbs to express some of action tenses.

8. Ondan xahiş edirəm ki, çox danışmasın.

on dan xahr $\int$ ediræm $\mathrm{kI}, \quad \mathrm{t} \int \mathrm{x} \quad \mathrm{danuf} \quad \mathrm{ma}$ suin

le de demande fais pro. rel. beaucoup parler (rad.) nég. $3^{\mathrm{e}}$ pers. sing. (impér.)

[onnan xahI elıræm ke, t $\int \mathfrak{x}$ danumasun]

$=$ Je le prie de ne pas beaucoup parler. (I request him not to speak too much.)

Four possible mistakes can be made in translating this statement. At the beginning, $40.74 \%$ of the learners have forgotten to use the propositions of verbs "prier" or "demander". $6.25 \%$ of the studied subjects of intermediate levels made mistake in realizing the correct position of "ne pas" in the sentence. Also, most Turkish speakers have incorrectly added "beaucoup" at the end of the sentence. And finally, 14.28\% of the beginners apply the term "de lui" at the beginning of the sentence, which could indicate the effect of the word order in their native language.

9. Sən bu axşam neçə cümlə yazmısan?

sæn bu axjam net 2 dzymlæ jaz mu san

tu ce soir combien phrase écrire (rad.) aff. passé comp. $2^{\mathrm{e}}$ pers. sing.

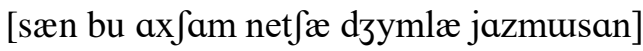

Int.J. Hum. Soc. Dev. Res.

Volume 3, № 1, 2019. 32-44 
= Combien de phrases est-ce que tu as écrites ce soir? (How many sentences have you written this evening?)

In Turkish language, there is no difference between "quelque" and "combien", or in other words, it uses the same term "neçə" as the equivalent for these two French words, which has led $51.18 \%$ learners to use "quelque" mistakenly. $37.03 \%$ of the studied subjects not only did not add "de" after "combien", but also did not add the sign "s" to the word "phrase". It should also be noted that most of the students did not pay attention to the gender and quantitative meaning of the nouns in questioned sentences of the French language.

10. Gülə-gülə gəlirdi.

$\begin{array}{cccc}\text { fylæ-fylæ } & \text { Jæl } & \text { Irdi } & \varnothing \\ \text { riant } & \text { venir (rad.) } & \text { aff. imp. } & 3^{\mathrm{e}} \text { pers. sing. }\end{array}$

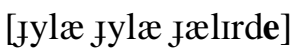

$=$ En riant, il venait. (He came while he was laughing.)

In this statement, it is seen that the use of subject adjective for learners has not caused problems. On the one hand, since the adjective in Turkish is usually placed at the beginning of sentence, this makes the transfer from mother tongue to a foreign language positive and, on the other hand, the subject adjective in the French language does not have special position and can be placed at the beginning or the end of sentence.

11. Bütün bunlar nəyə lazımdır?

$\begin{array}{ccccc}\text { bytyn } & \text { bunlar } & \text { næjæ } & \text { lazum } & \text { dur } \\ \text { tout } & \text { ceux-ci } & \text { pourquoi } & \text { nécessaire } & \text { est }\end{array}$

[bytyn bular næjæ lazımde]

= Tout cela sert à quoi ?/à quoi ça sert ? (What is the use of all of them?)

In this sentence, most studied students also made mistake in distinguishing the correct position of vocabularies of sentence; some of them have used the phrase "c'est pourquoi?" Or they have translated word-for-word from Turkish, some of them have used the verb "se servir" instead of the verb "servir" that this error could originate from their native language, because in Turkish, the two verbs "se servir" and "servir" have the same semantic meaning.

12. Nə üçün onu mənə demədin?

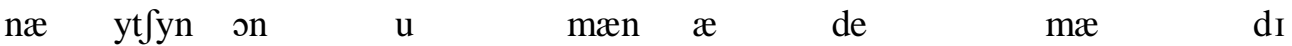
n 
quoi pour le aff. accus. je à dire (rad.) nég. aff. passé $2^{\mathrm{e}}$ pers. sing.

[næjæ one mænæ demædın]

= Pourquoi ne me l'as-tu pas dit? (Why you did not tell me that?)

Most learners have preferred to consider the tune of question in translating their sentence, while the standard French recommends the displacement of the subject and the verb in this case, and even the use of the expression "est-ce que" seems less likely to be used in questioned sentences; $11.11 \%$ of Turkish learners did not correctly identify the vocabularies position, and made mistakes in proper arrangement of pronouns and even the negative adverb of "ne". It should also be noted that some beginners have difficulty in recognizing the correct position of "pas".

13. Mən nə bədbəxtəm!

mæn næ bædbæxt æm

je que malheureux suis

[mæn næ bædbæxtæm] (pas de différence)

$=$ Comme je suis malheureux $!($ How I am miserable!)

The effect of the source language on the construction of sentence 13 is also well visible. In fact, the Turkish language uses a single word for all French expressions "comment", "quel", "comme" and "que", which leads to a serious problem for the studied subjects (especially beginners and intermediates), and 29.62\% of them even used the French phrase "combien" rather than exclamation phrase of "comme" or "que" to convey the surprise sense to their sentences, which would certainly not be correct.

14. Bu nə bədbəxtlikdir!

bu næ bædbæxtlık dir

ce que malheur est

[bu næ bædbæxtfuluxde]

$=$ Quel malheur ! (What a misery is this!)

In this sentence, more beginners and intermediate learners have not only repeated the mistakes made in the previous sentence, but also added "est" to "Quel malheur!" due 
to the effect of their native language, which is not grammatically acceptable in French (*Quel malheur est!).

15. Hansı kitabı axtarır?

hansu kItab u $\quad$ axtar $\quad$ ur $\quad \varnothing$

quel livre aff. accus. chercher (rad.) aff. prés. $\quad 3^{\mathrm{e}}$ pers. sing.

[hanse kitabe axtarur]

= Quel livre cherche-t-il? (Which book is he searching for?)

The only significant problem found amongst the beginners and intermediates is that $29.62 \%$ of Turkish studied students in this study have not been willing to use the interrogative phrase "est-ce que" or the displacement of the verb and subject once again.

16. Heç kəs yox idi .

het $\quad$ kæs jox IdI

aucun personne non était

[he] kæs jox Ide]

= Il n'y avait personne. (Nobody was there.)

In this sentence, $25.92 \%$ of the learners have forgotten to remove the second part of the negative phrase of French language. In fact, when the word "personne" appears in a negative sense in French sentences, the second part of the negative term "pas" should not be used, and this is also used when the "personne" acts as the subject of sentence and also has the role of object in the sentence.

17. $\mathrm{O}$ artıq danışmaq istəmir.

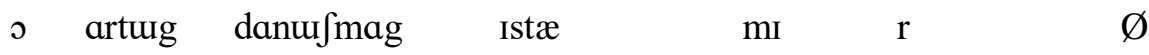

il plus parler vouloir (rad. nég. aff. prés. $3^{\mathrm{e}}$ pers. sing.

[o artux danufmax istæmir]

= Il ne veut plus parler. (He does not want to talk anymore.)

The only thing that has been neglected in this sentence is the recognition of correct position in the French sentence. In fact, some learners have used "plus" before the verb "vouloir" due to the influence of their mother tongue (14.81\%), while others $(29.62 \%)$ have not used it between the two verbs. The French grammar also does not allow the 
term "plus" to be used in the negative sense with the second part of the negative term "pas", which has caused mistakes in most of the elementary and a number of intermediate levels.

18. Mən sizə öz kitabımı verirəm.

mæn sIz æ $\quad$ kItab um $\quad$ u $\quad$ ver $\quad$ Ir æm

je vous à morph. emph. (poss.) livre mon aff. accus. donner (rad.) aff. prés. $1^{\text {re }}$ pers. sing.

[mæn sizæ œz kitabume veræm]

$=\mathrm{Je}$ « vous » donne « mon propre livre ». (I give my own book to you).

Only $28.57 \%$ of the studied beginners used mistakenly the direct object "mon propre livre" preceding the indirect object "vous", which, according to the position of the sentence, is not acceptable in grammar of the French language. Also, few learners have forgotten to add the adjective "propre" before the noun "livre".

19. Mən ona pul verdim.

mæn on a pul ver $\quad$ dI $\quad$ m

je le à argent donner (rad.) aff. passé $\quad 1^{\text {re }}$ pers. sing.

[mæn ona pul verdım] (Pas de différence)

= Je lui ai donné de l'argent. (I gave him some money.)

In the French structure, $74.07 \%$ of Turkish learners have forgotten to add the word "de" before the noun "argent", which shows the effect of learner's mother tongue, since the Turkish language does not use propositions to express indeterminate quantities. Using the direct object pronoun " 1 " instead of the indirect object pronoun "lui" in the translation of the above sentence is another mistake made by $18.51 \%$ of the beginners, which is explained in the third sentence.

20. Ondan mənə ver!

on dan mæn æ ver $\varnothing$

ça de je à donner (rad.) $\quad 2^{\mathrm{e}}$ pers. sing. (impér.)

[onnan mænæ ver]

Int.J. Hum. Soc. Dev. Res.

Volume 3, № 1, 2019. 32-44 
$=$ Donne-m'en ! (give me some of it!)

In $25.92 \%$ of the translations, the pronoun "en" preceded the pronoun "m" under the influence of the Turkish language. However, according to the grammar of the French language, the pronoun " $\mathrm{m}$ " must precede the pronoun "en" in the arrangement of words. The majority of the beginners has neglected the" $s$ "of verb in the French sentences. It should also be noted that a small number of this level has also added the word "de" between the verb "donner" and the pronoun "en", which is influenced by the Turkish as well as the Persian languages.

\section{Conclusion}

As a conclusion, it can be said that the structural difference between the Turkish and French languages has led a fairly significant number of French language learners to display the effect of their mother tongue in the learning process. Turkish language is among combined languages, while French is classified into analytical languages. In fact, Turkish grammar offers several morphemes (grammar or words) in the form of a single word for expressing different linguistic roles, but in French, the independent words do this task. Therefore, this has made it difficult for learners to make good progress.

The study of sentences made by French language learners shows that these subjects, influenced by their mother tongue, often made mistakes in determining the correct position of the pronouns, adjectives, and direct and indirect object. It should also be noted that they had more problems in making negative sentences and questions. In addition, since the Turkish language lacks specific vocabulary for the definite and indefinite articles, learners have sometimes forgotten the use of them. On the other hand, other problems that students have encountered in this research are related to the lack of use of the appropriate phrasal verbs and the rules for matching the number and gender of adjectives that the Turkish language is alien to. Finally, it should be acknowledged that while the influence of the Turkish language is indisputable in theprocess of learning, the other area that attracted our attention during this research was the effect of the Turkish multilingual language in their learning process, which will be important to study it carefully.

\section{Note}

The following graph shows the coefficient of French linguistic elements that the studied students, influenced by their mother tongue, have not been able to receive them as it should and possibly be. 


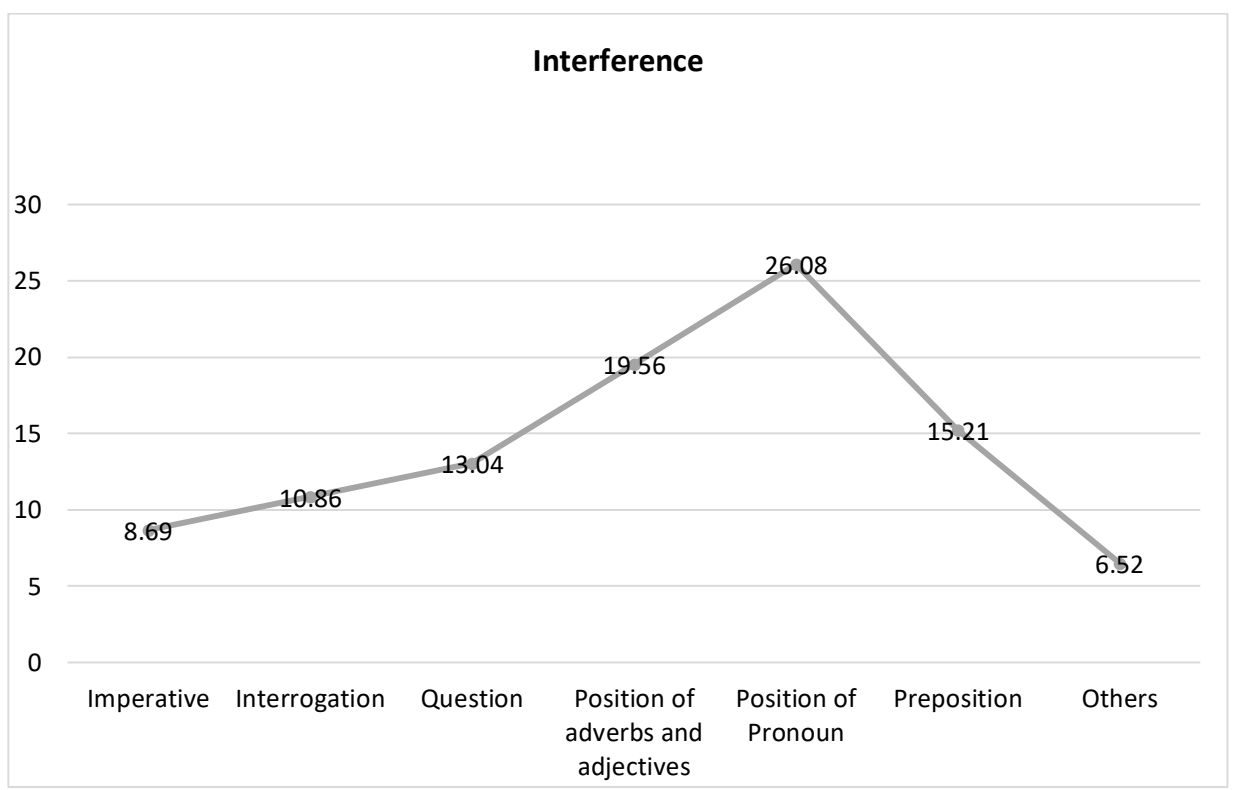

\section{Disclosure statement}

No potential conflict of interest was reported by the authors.

\section{Contact Information}

E-mail: rahnama.behrooz@gmail.com

Int.J. Hum. Soc. Dev. Res.

Volume 3, № 1, 2019. 32-44 


\section{References and notes:}

Bayani, A. (2013). Read and write like this, Tabriz: Akhtar.

Delatour, Y. (1991). Grammaire du Français: Cours de la Civilisation Française de la Sorbonne, Paris: Hachette.

Germain, C. (1993). Le Point Sur L'approche Communicative en Didactique des Langues,

Quebec: Centre Educatif et Culturel Inc,

Golstein, B. (1999). Grammaire du Turc : Ouvrage Pratique à L'usage des Francophones, ParisMontréal: L'Harmattan.

Grevisse, M. (1980). Le Bon Usage, Paris-Gembloux: Duculot.

Haghparast Gharamaleki, H. (2007). An analysis of Azeri Turkish through mathematics, Tehran: Andisheh Aria.

Haneda, K. [Translator: Sadigh, H. M.] (2008).Tabrizi vocabulary: an Azeri Turkish dialect in Iran, Tabriz: Yaran.

Heyat, J. (1986). A History of Turkish language and its dialects, Tehran: No

Karang, A. (1962). Contemporary Azerbaijani grammar, Tabriz: Mohammadi.

Khalkhali, A. (2009). Turkish grammar, Tabriz: Yaran.

Mahmudova, S. (2012). Analyse Syntaxique des Proverbes Azerbaïdjanais, University of Languages: Bakou.

Mamizadeh, E. \& Shibani Asl, S. (2000). Azeri Turkish on trip, Tehran: Standard.

Mirza Baba Tabib Ashtiani, M. (2007). Turkish grammar, Karaj: Pinar.

Rahmani Khiavi, S. (2013). Azerbaijani grammar, Tabriz: Akhtar. 